\title{
PHEROMONE SYNERGISTS AS CO-ATTRACTANT FOR OLFACTORY TRAPPING OF SCAPANES AUSTRALIS BSDV. (COLEOPTERA: SCARABAEIDAE) PEST OF COCONUT IN PAPUA NEW GUINEA
}

\author{
Titus Kakul ${ }^{1 /}$, Didier Rochat 4", Jean Paul Morin ${ }^{3)}$, P. Gende ${ }^{2 /}$, S. Embupa ${ }^{2)}$ \\ And L. Ollivier ${ }^{3 /}$
}

\begin{abstract}
Olfactory trapping of Scapanes australis is being studied to develop it to complement existing control methods. Components required were traps, pheromone and pheromone synergist. The first two have been developed while field trials carried out to determine an efficient synergist co-attractant is reported. Synthetic synergist mixtures of compounds emitted from fermenting sugarcane were tested in comparison to split stalk of garden grown sugarcane and split bulb of nursery coconut. Some of the mixtures produced synergistic effect similar to sugarcane but lower than split bulb of coconut. Placing live Scapanes adult inside the stalk of sugarcane increased catches similar to the split bulb of coconut. This will enable the formulation of an efficient tool of beetle control.
\end{abstract}

Keywords: Coconut, Scapanes, beetle, trapping, aggregation pheromone, and, kairomones

\footnotetext{
1/ Cocoa \& Coconut Research Instutute (CCRI), P. O. Box 642, Madang, Papua New Guine.a Email: ccriento@datec.net.pg;

2/ Cocoa \& Coconut Research Institute (CCRI), P. O. Box 1846, Rabaul, Papua New Guinea;

3/ Centre International de Recherche Agronomique pour le Developpement (CIRAD-CP), TA 80/PS3, Bd de la Lironde 34398, Montpellier Cedex 5, France; Email: : ollivier@cirad.fr;

4/ Institut National de la Recherche Agronomique (INRA) UR 258, 78026, Versailles Cedex, France. Email:
} 


\section{INTRODUCTION}

Two major beetle pests of coconut are problematic in Papua New Guinea (PNG). The first is a dynastinae, Scapanes australis Boisduval (Coleoptera, Scarabaeidae). Sa and the second is a weevil, Rhynchophorus bilineatus Mont. (Coleoptera, Curculionidae). Sa is a very difficult pest to control because of: firstly, its long lifecycle (367 days from egg to adult) and secondly, a nonseasonal reproductive behaviour and it attacks palms from the time of planting to seven years old. However, its reproductive behaviour, involve the emission of an aggregation pheromone and this provides an opportunity for olfactory trapping as a control option (Kakul, et al., 1999; Prior, et al., 2000).

The identification and synthesis of the pheromones of R.bilineatus (Oehlsclager et al., 1995), Sa (Rochat et al., 2000a) and O. rhinoceros (Hallett et al., 1995) have paved the way for olfactory trapping. However, the pheromone is less attractive on its own and it needs the combining of a plant kairomone to get more beetle optimal catches in the traps. In most cases the kairomones enhances the efficiency of the pheromone by acting as a synergist (Rochat $e t$ al., 2002 for Sa, Hallet 95 for Rb, Sudharto, 2001 for sugarcane stalk and coconut are being used as source of kairomones in traps to lure the beetles but they deteriorate very rapidly and lose synergistic effect after peaking on the $5^{\text {th }}$ day with 3 days. A substitute of the natural plant material which is fastidious and requires expensive servicing is required in the form of synthetic, efficient and persistent pheromone.

In the present paper field tests with synthetic mixtures as potential pheromone synergists for trapping $\mathrm{Sa}$, and also deliberate on the effect of using live beetles as modifiers of natural plant materials in an attempt to prolong synergistic combining effect with the pheromones of Sa are presented.

\section{MATERIALS AND METHODS}

The pheromone used in the trials was the blend of $(+) 2-$ butanol $(99.5 \%)$ and 3-hydroxy-2butanone (97\%) (Both Fluka product, Switzerland) in a $90: 5(\mathrm{v} / \mathrm{v})$ ratio and this was packaged in plastic dispensers $(10 \times 7 \mathrm{~cm})$ emitting $67 \mathrm{mg} /$ day.
The bucket traps (Kakul et al., 1998) were used in the field trials. These are plastic bucket containers with two large holes cut out in the side and with an inner inserted box containing the plant material used as synergist. The traps were hung $1.5 \mathrm{~m}$ from the ground and placed 50 meters apart in the trapping area.

All the field trials were carried out in East New Britain province of Papua New Guinea in complete randomised block design. Trial 1 was carried out at Sikut, Trial 2 at Gunanur plantation and trial 3 at Kevera plantation; the latter two sites in cocoa plantings with interspersed coconuts. The beetles in the traps were counted and removed every other day. Each bucket trap included a pheromone dispenser and a co-attractant.

\section{Testing of Pheromone co-attractants}

Trial 1 compared the response of $\mathrm{Sa}$ to synthetic synergist developed for $R$. palmarum (Rochat et al., 2000) as a possible co-attractant Sa. This trial was established with six treatments, all containing a Sa pheromone dispenser with: T1: Control nothing applied; T2: natural co-attractant stalk of sugar cane $20 \mathrm{~cm}$ long, weighing about 200g cut into two halves; T3: split bulb of a nursery coconut seedling (weighing about $500 \mathrm{~g}$ ); T4: synthetic co-attractant MCO; T5: synthetic co-attractant MAJ; T6: synthetic co-attractant BIS. Table 1 gives the composition of these synthetic mixtures. $\mathrm{MCO}$ is the mixture of $\mathrm{H}$ (ethanol+ethyl acetate and a minority fractions) reported as an efficient pheromone synergist for the American palm weevil by Rochat et al. (2000). MAJ is a $50: 50(\mathrm{v} / \mathrm{v})$ mix of ethanol and ethyl acetate also exhibiting interesting synergistic properties with the pheromone of the same species. BIS is also a mixture of ethanol+ethyl acetate plus some minority components.

The synthetic mixtures were packaged in heat-sealed plastic sachets with diffusion rates of 300 to $400 \mathrm{mg} / \mathrm{day}$. The trial was established with six replicates $(1$ replicate $=$ itrap $)$ and carried out from the 9th to $28^{\text {th }}$ February 2000.

\section{Trial 2. Testing of sugar cane with live male SA as modified plant material}

The plant synergist constitute pieces of sugar cane placed inside a box in the traps. In the 
previous trial 1 it was less attractive than pieces of coconut. Trial 2 tested the effect of sugarcane with live and feeding Sa to prolong the attractiveness of the synergist than the effect of sugarcane alone. The trial was set up with the network of traps at the Gunanur estate. The treatments were: (1) Split bulb of nursery coconut (CB), (2) Live male Sa in Sugarcane stem (MS) and (3) Live female $\mathrm{Sa}$ in sugarcane stem (FS) designed with 10 replicates (1 trap $=1$ replicate) .

Trial 3. Testing sugarcane with live Sa as synergistic device, plant material and comparing to split sugarcane and pieces of coconut

Trapping with sugarcane and live active male combined with a pheromone dispenser led to an increase in catches similar to the effect of the use of coconut fragments synergist. Trial 3 was therefore carried out to determine whether this increase was due to the presence of the additional compounds produced by the male, or simply due to the greater amount of volatile compounds caused by the continuous feeding and decomposing sugarcane broken by the insect. This trial compared the following treatments: sugarcane with male or female and piece of coconut as control: T1: no co-attractants; T2: split stalk of sugarcane without insect; T3: live male Sa inside sugarcane stalk; T4: live female $\mathrm{Sa}$ inside sugarcane stalk; and, T5: split bulb of nursery coconut. All traps contained SA pheromone dispenser and the treatments were replicated 5 times.

\section{Statistical analysis}

In all experiments, mean total catches of $\mathrm{Sa}$ per trap was subjected to one-way ANOVA (co-attractant) using Microsoft excel software after square root transformation $(\mathrm{x}+0.5)$ for residues normalization. The means were compared using the same program me.

\section{RESULTS}

The results from field trial 1, testing the response of $\mathrm{Sa}$ to synthetic synergist is shown on figure 1 . The best result or higher beetle catch was obtained with treatment 3: split bulb of nursery coconut as the synergistic material (6.8 insects per trap per week). Captures were low in other treatments. The bait effect was significant $(\mathrm{P}<0.001)$. Combined with the pheromone, split coconut bulb produced a high response, making it possible to catch significantly more Sa than all the other co-attractants, whose effects were equivalent. The effects of the synthetic mixtures were similar to the sugarcane synergist.

The effect of bait in trial 2 was similar for each treatment (no significant difference). Live SA of both sexes has renewed the synergism of the sugarcane resulting in increase in beetle captures to the level of coconut host plant synergist (Figure 2).

The effect of live SA bait was significant at $\mathrm{P}<0.01$ in field trial three (Figure 3 ). The mean of the catches with live male and female $\mathrm{Sa}$ was significantly $(\mathrm{P}<0.01)$ higher than the other treatments $(1.9$ and 1.4 beetles/trap/week not et al. 0.8 and 0.9 for split sugar cane and coconut bulb respectively). The traps containing one live male captured more SA than the traps containing one live female $(\mathrm{P}<0.05)$.

\section{DISCUSSION}

Naturally, wounds on palms will attract both Scapanes and Rhynchophorus adults. Rhynchophorus larvae and adult Sa feeding in the wounded palms produced exudates that ferments all the time, rendering wounded palm very attractive to the beetles. Any attempt to control the pest by olfactory trapping should make the bait more attractive than the natural scenario. The pheromone serves as along-range attractant in luring the beetles towards the traps and the plant volatiles are acting on the behaviour at close range to the source (Neelakanthi et al., 1995). The synergist effect of plant material is

frequent with beetle; Rhynchophorus sp. (Rochat et al., 2000); O.rhinoceros (Alfiler, 1999; Subharto et al., 2001); and O. monoceros (Allow et al., 2002).

In trial 1 the synthetic synergist effect was similar to the sugarcane, which was commonly used as synergist in traps but coconut was more attractive than other synergists tested. However the coconut synergism will peak after five days then decline following the completion of fermentation. The lost of synergism will reduce the efficiency of traps. Coconut bulbs are not easily available for 
use, as synergist and so other material with equal efficiency ought to be found.

The effect of continuous emission of volatiles from lacerated sugar cane tissues containing live Sa, were compared with split bulb of nursery size coconut in Trial 2 . The effect of the three treatments $\mathrm{CB}, \mathrm{M} \mathrm{S}$ and FS did not differ. Trial 2 demonstrated that the feeding and burrowing activity of the live $\mathrm{Sa}$ modified the sugarcane and prolonged its co-attractant property, likely by constantly exposing new lacerated or chewed tissues which ferment and continuously emit the plant volatiles acting on the beetle behaviour. The attractiveness provided by the wounded host plants had been reported to increase in the field in 3 days then to reach a peak during 2 days and after to decline (Morin et al., 1986). By means of including live beetles and letting them to continue feeding inside sugarcane in traps, increases and prolong the synergistic effect of plant material, and so provide an efficient attractant for a much longer period.

In trial 3 , a greater number of beetles were captured in traps containing live beetles inside sugarcane stalk. The result was probably due to a double effect of the additional pheromonal compounds produced by the male and the greater amount of volatiles compounds caused by the decomposing sugarcane chewed by the insects. The two treatments using live beetle inside sugarcane stalk caught significantly more SA than the treatment using other synergists. In trial 3 , it was observed that the coconut bulb synergist and sugar cane pieces without beetle have dried up rapidly leading to a reduction of fermentation and their synergistic effect. A quick desiccation of the plant material during the dry season is probably the reason why coconut bulb was no better than sugarcane in this trial.

The population of $\mathrm{Sa}$ is usually low during the dry season, however it is a key pest and economic loss does occur during the dry season also. Results from the field Trial 3 conducted during the dry season, also further strengthen the advantage of using modified sugarcane which prove efficient synergist while the other synergists were rapidly exhausted. In the tropical regions, vegetal synergist dries very rapidly during the dry season but this can be overcome by the use of live $\mathrm{Sa}$ feeding into sugarcane causing its decomposition leading to a progressive release of volatile compounds and prolong the synergist effect in traps. When ever possible, it is better to use male Sa which produces additional compounds in night during the calling periods.

\section{ACKNOWLEDGEMENTS}

R. Minana for persistence commitment to field trapping and assessment. Coconut Product limited and NewMark Plantation Management Ltd., for allowing us to use Gunanur and Tokiala plantation for some of the field trials. This paper had been published with the permission of the board of PNCCCRI. We are also indebted to the European Union for funding under INCO project Number RBIC 18CT970199. We would like to thank our colleagues, Dr. Yoel Efron and Mr. Martin Powel, for constructive criticism of the manuscript.

\section{CONCLUSION}

Field-testing of synthetic co-attractant synergists had not yet provided any mixture as efficient as split bulb of coconut, but only as efficient as split sugarcane stalk, which is less efficient than coconut bulb by far. Putting one live $\mathrm{Sa}$ beetle in sugarcane nevertheless enhance the efficiency of the pheromone by prolonging release of plant volatiles and increasing catches to equal or better than the coconut bulb synergist. The sugarcane can be grown by the farmer on farm and Sa can be collected from the first traps set up in the field. Their use will enable the co-attractants to be maintained at an optimal efficiency for long period till replenished.

\section{References cited}

Alfiler A. R. (1999). Increased attraction of Oryctes rhinoceros aggregation pheromone, ethyl 4-methyloctanoate, with coconut wood. CORD (Special Ed.) 15(2); pp.106-114.

Allou, K., Morin, J.P. and Rochat, D. (2002). Amelioration $\mathrm{du}$ piegeage olfactif de Oryctes monoceros (Ollivier), Coleoptera, Dynastidae, ravageurdu cocotieretdu palmier a huile en Cote d'ivoire. AFPP-sixie me Conference international su $\mathrm{r}$ les ravageurs 
en Agriculture. Montpellier, 5-6 Decembre 2002. pp.295-302

Kakul, T. Laup, S. Morin, J.P. Beaudoin -Ollivier, L. Rochat D, Prior, R.N.B. and Gende, P. (2002). Models for traps used for trapping major pest of coconuts Rhyncophorus bilineatus, Scapanes australis and Oryctes rhinoceros in Papua New Guinea. Submitted for publication in CORD.

Kakul, T., Laup, S., Stathers, T., BeaudoinOllivier, L., Morin, J-P., and Rochat, D. (1999). Trapping and disruption of the mating activity of Scapanes australis using live male as bait in Papua New Guinea. CORD 15 (2), pp.131-145.

Hallet, R. H., Perez, A. L., Gries, G., Gries, R., Pierce, H.D.Jr., Yue, J., Oehlschlager, A. C., Gonzalez, L. M., and Borden, J.H., (1995). Aggregation pheromone of the coconut rhinoceros beetles oryctes rhinoceros (L) (Coleoptera: Scarab). J. Chem. Ecol. 21:1549-1570.

Morin, J. P., Lucchini, F., De, Araujo, J. C. A., Ferreira, F.M.S., and Fraga, L. S. (1986). Le controle de Rhynchophorus palnnmarum par piegeage a I'aide de moreeaux de palmier. Oleagineux 41: pp.57-59.

Neelakanthi, E. Gunawardena and Hearath, H. M.W.K.B. (1995) Enhancement of the activity of ferrugineol by $\mathrm{N}$ - Penta nol in an attractant baited trap for the coconut pest, Rhynchophorus ferrugineus F. (Coleoptera: Curculionidae) J. Natn. Sci.Coun. SriLanka, 23(2): pp.81-86.

Oehlschlager, A.C., Prior, R.N.B., Perez, A.L., Gries, R., Gries, G., Pierce, H.D. Jr. and Laup, S. (1995). Structure, chirality, and field testing of a male-produced aggregation pheromone of Asian palm weevil Rhynchophorus bilineatus (Montr) (Coleoptera: Curculionidae). Journal of Chemical Ecology 21: pp.1619-1629)
Prior, R.N.B., Morin, J.P., Rochat, D., Beaudoin-Ollivier, L., Stathers, T., Kakul. T., Embupa, S., Naguai, R. (2000). New aspects of the biology of the Melanesian Rhinoceros beetle Scapanes australis (Col: Dynastidae) and Evidence for field attraction to males. Joumal of Applied Entomology, 124: pp.41-50.

Sudharto P.S., Purba R. Y., Rochat D. and Morin, J.P. (2001). Synergy between empty oil palm fruit bunch and synthetic pheromone (Ethyl 4-methyloctanoate) for mass trapping of Oryctes rhinoceros beetles in the oil palm plantation in Indonesia. PORIM International Palm Oil Congress, Kuala Lumpur, Malaysia, Aug. 20-23.

Rochat, D, Nagnan-le Meillour, P., Esteban-Duran, J.R., Malosse, C., Perthuis, B., Morin, J.P., and Descoins, C. (2000a). Identification of pheromone synergists in American palm weevil, Rhynchophorus palmarum, and attraction of related Dyna mis borassi. Journ. Chem. Eco., 26(1); pp.155-187. 
Table 1. Composition of the potential synthetic

Kairomone blends tested for synergy in trial 1.

\begin{tabular}{|l|r|r|r|}
\hline \multicolumn{1}{|c|}{$\begin{array}{c}\text { Mixtures } \\
\text { (in ML) }\end{array}$} & MAJ & MCO & \multicolumn{1}{c|}{ BIS } \\
\hline Ethanol & 500 & 393 & 375 \\
\hline Ethyl acetate & 500 & 441 & 375 \\
\hline Acetic acid & - & 7.1 & \\
\hline 2-Methylbutanol & - & 0.9 & \\
\hline Isobutyle acetate & - & 4.5 & \\
\hline Isoamyl acetate & - & 13.3 & \\
\hline Ethyl proionate & - & 4.5 & 75 \\
\hline Ethyl butyrate & - & 4.5 & \\
\hline Ethyl isovalerate & - & 0.9 & \\
\hline Propyle acetate & - & 0.9 & \\
\hline Methanol & - & 4.5 & \\
\hline Acetaldehyde & - & 0.9 & \\
\hline 2,3-Butanediol & - & 4.5 & \\
\hline 2-Phenylethanol & - & 17.5 & \\
\hline Phenol & - & 13.2 & \\
\hline Guaiacol & - & 8.7 & \\
\hline Ethyl octanoate & - & 8.7 & \\
\hline Ethyl decanoate & - & 0.9 & \\
\hline 2-Hexacon & - & 0.9 & \\
\hline 2-Heptanone & - & 8.7 & \\
\hline 2-Nonanone & - & 1.8 & \\
\hline Acetoine & - & 4.4 & \\
\hline $\begin{array}{l}\text { Alpha- } \\
\text { phellandrene }\end{array}$ & - & 43.9 & \\
\hline Mentone & - & 1.8 & \\
\hline 3,3- \\
$\begin{array}{l}\text { Dimetylacrylate } \\
\text { d'ethyle }\end{array}$ & - & 0.9 & \\
\hline Ethyl tiglate & - & & \\
\hline Hexanol & - & 1.8 & \\
\hline Total (in ml) & 1000 & 1000 & \\
\hline
\end{tabular}

